\title{
The Influence of Inquiry Learning Model and Achievement Motivation on HOTS Economic Learning Outcomes on $11^{\text {th }}$ Grade Students
}

\author{
Prima Lestari Situmorang ${ }^{1}$, Indra Maipita ${ }^{2}$, M. Fitri Rahmadana ${ }^{3}$ \\ ${ }^{1}$ Postgraduate Student of Economic Education, Universitas Negeri Medan, Indonesia \\ ${ }^{2}$ Dean of Economic Faculty, Universitas Negeri Medan, Indonesia \\ ${ }^{3}$ Postgraduate Lecturer of Economic Education, Universitas Negeri Medan, Indonesia \\ Primalestari90@gmail.com
}

\begin{abstract}
This study aims: (1) to know the difference between HOTS Economic learning outcomes taught by the Guided Inquiry learning model and the modified free inquiry learning model; (2) knowing the difference between HOTS Economic learning outcomes for students who have high achievement motivation and HOTS Economic learning outcomes for students who have low achievement motivation; and (3) knowing the interaction between inquiry learning models and achievement motivation on learning outcomes. The population in this study are all social studies 11th grade students in Senior High School 5 Medan, amounting to 3 classes. The sample in this study is determined randomly by random sampling technique, by taking 2 classes with a total of 34 students per class. The research method uses quasiexperimental. The instrument of this study is the achievement test and achievement motivation test. Analysis of the data used is Anvaa Factorial $2 \times 2$. Based on the research results obtained: (1) there are differences in the results of HOTS Economic student learning taught by the Guided Inquiry learning model and Guided Inquiry learning outcomes of students taught by the Modified Free Inquiry Learning Model (Modified Free Inquiry) with fcount>Ftable (4.15> 3.9); (2) there are differences in economic learning outcomes of students who have high achievement motivation and students who have low achievement motivation with fcount>Ftable (171.07> 3.9); (3) there is an interaction between inquiry learning models and achievement motivation on learning outcomes HOTS Economic with fcount>Ftable (4.04> 3.9).
\end{abstract}

Keywords: Guided inquiry; modified free inquiry; achievement motivation; results study.

\section{Introduction}

Writing about HOTS is one of the most important issues in the education system. Every teacher is expected to be able to arrange HOTS questions so students do not only answer items that only measure at the $\mathrm{C} 1$ level (knowing), $\mathrm{C} 2$ (understanding), $\mathrm{C} 3$ (applying) but are also able to answer questions at the C4 level (analysis), C5 (evaluation ) and C6 (creative). So that each student is able to Increase the achievement of learning outcomes and Increase motivation to learn (Brookhart, 2010).

Based on preliminary study activities carried out at Senior High School 5 Medan, it was found that the average score of the UN Economic Social Sciences Department in 2018 tended to be relatively good at 8.78. Although this achievement indicates the academic quality of individual students at the national level, it does not yet illustrate how far their academic competitiveness is at the global level when compared to the results of the Trends in International Mathematics and Science Study (TIMSS) survey. Indonesia's ranking is ranked 46 out of 51 countries and scores 397 and the Survey Program for International Student Assessment (PISA) are ranked 69 out of 76 countries and a score of 386 . This shows that nationally may obtain high average scores but do not yet demonstrate the quality of 
competing human resources. Many of the questions contained in TIMSS and PISA have not been included in the Exam questions both at school and nationally which make it difficult for teachers to develop the same form of questions.

The design of economic learning that is used by teachers in lesson plans is still dominant using conventional approaches that still emphasize lecture activities, learning discussion through exposure to material that tends to be passive so that learning occurs in one direction, students who only receive information in the abstract. The teachers have not fully implemented active and creative learning in involving students and have not used various learning models that vary based on the character of the subject matter. In addition, the teacher is still fixated on the textbook as the only source of teaching and learning so that the student's brain is forced to remember and hoard various information without being required to understand the information obtained to link it to the situation.

Deluca (2011) states that to develop higher-order thinking skills students must first understand factual, conceptual, and procedural knowledge applying their knowledge to learning by doing and then contemplating the process that produces a solution. The teacher can do this by guiding students through observational activities, concept formation, responding, analyzing, comparing and giving the necessary consideration. Student activeness and teacher guidance greatly contribute during learning (Zerihun et. Al, 2012). The learning process can be done if the teacher is able to prepare a series of activities well and planned.

One learning model that is in accordance with scientific characteristics and higherorder thinking is the inquiry learning model. Vygotsky's Contructivism learning theory assumes that the Inquiry model is learning that prepares a good situation for children to conduct their own experiments, in the broad sense of wanting to see what is happening, wanting to do something, seeking answers to their own questions, linking other findings, comparing what is found with what found by someone else. The general objective of the Inquiry Learning Model is to help students develop intellectual thinking skills and other skills such as asking questions and finding answers that begin with their curiosity. The use of inquiry learning as one of the learning models can help students to understand scientific concepts through practice and participation in scientific research activities together. Thus, inquiry learning models can improve HOTS because students can find concepts directly.

\section{Review of Literature}

Thomas and Thorne (2009) in the center of development and learning explained that "Higher Order Thinking Skill (HOTS) is thinking on a level that is higher than memorizing facts or telling something back to someone exactly the way it was told to you. HOTS takes thinking to higher levels than restating the facts and requires students to do something with the facts - understand them, infer from them, connect them to other facts and concepts, categorize them, manipulate them, put them together in new or novel ways, and apply them as we seek new solutions to new problems. "

That is, HOTS is thinking at a higher level than memorizing facts or recounting someone exactly as said before. HOTS requires thinking to a higher level than reaffirming and demanding students to do things with facts, understand them, draw conclusions, relate them to other facts and concepts, group, manipulate, put them together in new ways or have a novelty value and apply it by finding new solutions to new problems. 
Meanwhile According to Brookhart, Susan M (2010) the definition of HOTS is divided into three categories, namely:

1. Defined in terms of transfers. Transfers require students not only to remember but also to understand and be able to use what they have learned.

2. Defined into critical thinking. According to Norris and Ennis, critical thinking is reasonable, reflective, focused on determining what to believe or do. Burahal added, critical thinking includes reasoning, questioning, investigating, observing, describing, comparing, connecting, finding

3. Complexity and explore points of view.

4. Defined in problem solving. Nitko and Brookhart explained that problem solving is how to achieve the desired goals. Students must use one or more high-level thought processes.

While HOTS according to Anderson and Krathwohl's revision is a cognitive dimension of analyzing, evaluating, and creating. Here is an understanding of the dimensions of HOTS cognitive processes according to Anderson and Krathwohl.

Table 1. Dimensi Kognitif Anderson and Krathwohl

\begin{tabular}{|c|c|l|}
\hline TC & Taxonomy & \multicolumn{1}{c|}{ Definition } \\
\hline C4 & Analyzing & $\begin{array}{l}\text { Divide the material in several parts, determine the relationship } \\
\text { between parts or as a whole by making a decrease, management, } \\
\text { and recognition of attributes }\end{array}$ \\
\hline C5 & Evaluating & $\begin{array}{l}\text { Make decisions based on criteria and standards through checking } \\
\text { and criticism }\end{array}$ \\
\hline C6 & Creativing & $\begin{array}{l}\text { Develop new ideas, products, or methods by combining elements } \\
\text { to form functions as a whole and rearranging elements into new } \\
\text { patterns or structures through planning, development, and } \\
\text { production }\end{array}$ \\
\hline
\end{tabular}

Source: Anderson dan Krathwohl (2010: 403)

While according to Piaget (1969) inquiry is one of the lessons that prepares a situation for children to conduct their own experiments; in the broadest sense want to see what is happening, want to do something, want to use symbols and look for answers to their own questions, connect the findings of one with those found by others. While Sudjana (2004: 154) states that Inquiry is a teaching method that will create conditions for effective and conducive learning and facilitate and facilitate teaching and learning activities.

Based on the description of the experts, the researcher concludes that the inquiry method means a series of learning activities that explores students optimally involving all students' abilities by generating various potentials within students to investigate systematically, critically, logically, analytically, so students can find his discoveries with confidence.

In the modified free inquiry learning model, the teacher gives the problem then students are asked to solve the problem through observation, exploration and research. The teacher does not provide research procedures but students who search for research procedures themselves, students plan outline research procedures or experiments used to design and conduct research. Teachers provide limited and unstructured guidance Guided inquiry 
learning models are learning models where the teacher provides guidance structured procedures and guidance this can increase student motivation and achievement.

McClelland (1987) states that people who have needs or needs will improve performance, so that it will be seen about their ability to achieve. People who have high achievement motivation will have better performance when compared to people who have low achievement motivation. Parhusib (2009: 37) adds that achievement motivation is the desire to achieve superior predicates through serious learning.

McClelland (1987) states that the characteristics of people who have high achievement motivation are (1) having personal responsibility; (2) determine the value to be achieved or set superior standards, students determine the value to be achieved; (3) trying to work creatively. Students who are highly motivated, persistent, and actively seeking creative ways to complete their schoolwork; (4) trying to achieve goals; (5) able to complete moderate tasks; ; (6) do the best activities; (7) anticipating.

\section{Research Method}

This study is a quasi-factorial 2 x 2 ANAVA experimental study. The data collection instrument used was a matter of Higher Order Thinking Skills (HOTS) in the form of a description that was analyzed based on the Polya concept and used a questionnaire to measure student achievement motivation. Before conducting research, the instrument is first subject to content validation by material experts and psychologists. In addition, the instrument was also carried out a validation test. The population in this study were all social studies students in 11th grade as many as 3 classes with 97 students. How to take samples with Random Sampling (random sample) where the initial ability of students the same in each class.

\section{Discussion}

4.1Difference between HOTS Economic learning outcomes of students taught by Guided Inquiry learning models (Guided Inquiry) with HOTS Economics learning outcomes of students taught by the modified free Inquiry learning model (Modified Free Inquiry)

From the results of calculations with the Scheffe Test shows that $F_{\text {coun }}=1.9149$. For the value of the distribution of $\mathrm{F}_{\text {table }}$ at a significance level of $5 \%=2.74$. These results indicate that $\mathrm{F}_{\text {coun }}<\mathrm{F}_{\text {table }}(1.9149<2.74)$, thus providing a decision that the results of HOTS Economics learning outcomes of students taught by the Guided Inquiry learning model (Guided Inquiry) does not have a significant difference with HOTS Economics learning outcomes of students who taught with a modified free inquiry learning model (Modified Free Inquiry).

4.2 Difference between HOTS Economic learning outcomes of students who have high achievement motivation with HOTS learning outcomes Economics of students who have low achievement motivation.

From the results of calculations with the Scheffe Test shows that $F_{\text {coun }}=171,096$. For the value of the distribution of $\mathrm{F}_{\text {table }}$ at a significance level of $5 \%=2.74$. these results indicate that $\mathrm{F}_{\text {coun }}<\mathrm{F}_{\text {table }}(171,096>2.74)$, thus giving the decision that HOTS Economic learning 
outcomes of students who have high achievement motivation have a significant difference with HOTS learning outcomes Students who have low achievement motivation.

4.3 Difference in HOTS economic learning outcomes of students taught by guided Inquiry learning models (guided Inquiry) that have high achievement motivation with HOTS Economic learning outcomes of students who are taught with a modified Free inquiry learning model that has high achievement motivation

From the results of calculations with the Scheffe Test shows that $F_{\text {coun }}=1.1550$. For the value of the distribution of $\mathrm{F}_{\text {table }}$ at a significance level of $5 \%=2.74$. These results indicate that $\mathrm{F}_{\text {coun }}<\mathrm{F}_{\text {table }}(1.1550<2.74)$, thus providing a decision that HOTS Economics learning outcomes of students taught with guided Inquiry learning models (guided Inquiry) who have high achievement motivation do not have significant differences with learning outcomes HOTS Economics students are taught with a Modified Free inquiry learning model that has high achievement motivation.

4.4 Difference in HOTS Economic learning outcomes of students taught with guided Inquiry learning models (guided Inquiry) that have low achievement motivation with HOTS Economics learning outcomes of students taught with Modified Free inquiry learning models that have low achievement motivation.

From the results of calculations with the Scheffe Test shows that $F_{\text {coun }}=6.0897$. For the value of the distribution of $\mathrm{F}_{\text {table }}$ at a significance level of $5 \%=2.74$. These results indicate that $\mathrm{F}_{\text {coun }}<\mathrm{F}_{\text {table }}(6.0897<2.74)$, thus making the decision that HOTS Economic learning outcomes of students who are taught with guided Inquiry learning models (guided Inquiry) who have low achievement motivation have significant differences with HOTS learning outcomes Economic students are taught with a Modified Free inquiry learning model that has low achievement motivation

4.5 Difference in HOTS Economic learning outcomes of students taught with guided Inquiry learning models that have high achievement motivation with HOTS Economic learning outcomes of students taught with guided Inquiry learning models (guided Inquiry) that have low achievement motivation.

From the results of calculations with the Scheffe Test shows that $F_{\text {coun }}=121.427$. For the value of the distribution of $\mathrm{F}_{\text {table }}$ at a significance level of $5 \%=2.74$. These results indicate that $\mathrm{F}_{\text {coun }}<\mathrm{F}_{\text {table }} 121.427<2.74$ ), thus making the decision that HOTS Economics learning outcomes of students taught with guided Inquiry learning models (guided Inquiry) that have high achievement motivation have significant differences with HOTS Economics learning outcomes of students taught with the guided Inquiry learning model that has low achievement motivation.

4.6 Difference in HOTS Economic learning outcomes of students taught by the Modified Free inquiry learning model that has high achievement motivation with HOTS Economics learning outcomes of students taught with the Modified Free inquiry learning model which has low achievement motivation

From the results of calculations with the Scheffe Test shows that $F_{\text {count }}=52,687$. For the value of the distribution of $\mathrm{F}$ table at a significance level of $5 \%=2.74$. These results indicate that $\mathrm{F}_{\text {count }}<\mathrm{F}_{\text {table }}(52,687<2.74)$, thus providing a decision that HOTS Economic 
learning outcomes of students taught with the Modified Free inquiry learning model that has high achievement motivation has a significant difference with HOTS learning outcomes Economic students are taught with a Modified Free inquiry learning model that has low achievement motivation.

Based on the results of the study, there are differences in student learning outcomes taught by the guided inquiry learning model and student learning outcomes taught by the modified free learning model. This is evidenced by the average value of student learning outcomes in students taught by the Guided Inquiry learning model which is 79.67 while in students who are taught with a modified Free Inquiry learning model (Modified Free Inquiry) the average value of learning outcomes students namely 77.97. From the calculation of Anava obtained $F_{\text {count }}=4.15$. for the distribution value of $F$ table $=3.9$, these results indicate that $\mathrm{F}$ count $>\mathrm{F}_{\text {table }}(4.15>3.9)$, thus giving a decision that Ho is rejected and Ha is accepted. Thus, the proposed research hypothesis that HOTS Economic learning outcomes of students taught by the Guided Inquiry learning model is higher than HOTS Economics learning outcomes of students taught by the Modified Free Inquiry learning model.

The results of the second hypothesis show that HOTS Economic learning outcomes of students with high achievement motivation are higher than HOTS Economic learning outcomes of students with low achievement motivation. This shows that achievement motivation in learning is very significant to distinguish learning outcomes. Achievement motivation in this study can be divided into two, namely high achievement motivation and low achievement motivation. From the results of overall data analysis the average HOTS Economic learning outcomes with high achievement motivation are higher than HOTS Economic learning outcomes of students with low achievement motivation. This indicates that students with high achievement motivation on average have better HOTS Economic learning outcomes compared to students who have low achievement motivation.

Based on the results of the study, it can be seen that the learning outcomes of students with high achievement motivation are higher than students with low achievement motivation. This can be seen from the learning outcomes of students with high achievement motivation having an average value of 86.62 and the value of students with low achievement motivation with an average value of 71.5. In addition, the Anava test results also showed $F_{\text {count }}>F_{\text {table }}$ $(171,096>2.74)$, thus making the decision that economic learning outcomes in students with high achievement motivation have significant differences with economic learning outcomes in students with low achievement motivation.

The interaction between inquiry learning models and achievement motivation on

This study is evident from the results of the ANAVA calculation which shows that $\mathrm{F}_{\text {count }}<\mathrm{F}_{\text {table }}(1.1550<2.74)$, thus providing a decision that HOTS Economic learning outcomes of students taught with guided inquiry learning models that have higher achievement motivation compared to HOTS Economics learning outcomes of students who are taught with a modified free inquiry learning model that has high achievement motivation even though it does not have a meaningful difference. 


\section{Conclusion}

Based on the result, it can be concluded that with the acceptance of the first hypothesis proposed, namely the results of HOTS Economic learning students who are taught with a guided inquiry learning are higher than the results of HOTS learning taught by a modified free inquiry learning model in Senior High School 5 Medan. For this reason, it is necessary to develop guided inquiry efforts for high school students in 11th grade. The results of this study support previous research.

With the acceptance of the second hypothesis proposed, namely HOTS Economic learning outcomes in students who have high achievement motivation is higher than HOTS Economics learning outcomes in students who have low achievement motivation on students of Senior High School 5 Medan. That way the inquiry learning model can work well according to if students have high achievement motivation.

With the acceptance of the third hypothesis proposed, namely there is an interaction between the inquiry learning model and achievement motivation on student learning outcomes at Senior High School 5 Medan. The inquiry learning model is a learning model that prioritizes the process of finding scientific answers, so that during the formulation of hypotheses, students who have achievement motivation take an active role with the help of the teacher.

\section{References}

Anderson, L.W. \& Krathwohl, D. R. (Eds). (2015). Kerangka landasan untuk pembelajaran, pengajaran, dan asesmen: revisi taksonomi pendidikan.

Brookhart, S. M. (2010). How to Assess Higher-Order Thinking Skills in Your Classroo. Paper presented at the annual meeting of ASCD, Los Angeles.

Deluca. (2011). The GRIDc Project Developing Students's Thinking Skills in a Data-Rich Environment. Eric Journal, 23 (1).

Joyce, B. and Marsha W. (2009). Models of Teaching (Ed. $\left.\sigma^{\text {th }}\right)$. Unites States of America: Allyn \& Bacon.

McClelland, D. C. (1987). Human Motivation. New York : Cambridge University Press.

Parhusip, C. M. D., Mochammad A. M., et al. (2014). Pengaruh Disiplin Kerja Terhadap Prestasi Kerja ( Studi Pada KAryawan AJB BUMIPUTERA 1912 Cabang Kayutangan Kota Malang ). Jurnal Administrasi Bisnis (JAB), 9 (1).

Piaget, J.(1969). The Early Growth of Logic in The Child. New York: Norton.

Sudjana, N. (2015). Penilaian Hasil Proses Belajar Mengajar. Bandung :Remaja Rosdakarya.

Thomas, A. and Thorne, G. (2009). How to Increase Higher Order Thinking. Metarie, LA: Center for Development and Learning. (accessed on 6 march 2019).

Zehrihun, Z., Beisshunzein, J., \& Van Os, W. (2012). Student Learning Experience as Indicator of Teaching Quality. Educational Assessment, Evaluastion and Accountability, 24 (2): 99-111. 